\title{
Color development in rubberwood (Hevea brasiliensis) during kiln drying
}

\begin{abstract}
A study was conducted to measure how the color in rubberwood boards developed under standard kiln drying schedule. Edge-matched rubberwood boards were dried at 20, 40, 60 and $80 \%$ of the drying time to achieve the final moisture content of $12 \pm 2 \%$. Discoloration increased with higher temperature and drying time, while lower relative humidity tended to minimize discoloration. It is recommended that lower drying temperature and relative humidity schedules are used to minimize discoloration of rubberwood during drying.
\end{abstract}

Keyword: Color development; Drying temperature; Drying time; Final moisture content; Hevea brasiliensis; Kiln drying; Rubberwood 